\title{
Estudio de la absorción capilar y la sorptividad de hormigones con áridos calizos cubanos
}

\section{Study about the capillary absorption and the sorptivity of concretes with cuban limestone aggregates}

\author{
J. J. Howland ${ }^{(*)}$, A. R. Martín(**)
}

Recepción/Received: 4-X-12

Aceptación/Accepted: 25-III-13

Publicado online/Online publishing: 17-VI-13

\section{RESUMEN}

El objetivo del estudio fue demostrar la posibilidad de lograr en Cuba, con el empleo de áridos calizos de elevada absorción (mayores del 1\% en muchos casos), hormigones con valores de porosidad efectiva inferiores al $10 \%$ y de velocidad de absorción capilar (Sorptividad) inferiores a 5 x $10-5 \mathrm{~m} / \mathrm{s}^{1 / 2}$, tal como establece el documento elaborado por la RED DURAR del CYTED para estructuras expuestas a ambientes muy agresivos. Los resultados experimentales mostraron que con la aplicación del método de ensayo de absorción capilar de Göran Fagerlund se obtuvieron porosidades efectivas inferiores al $10 \%$ para relaciones agua/cemento de 0,4 y 0,45, pero los valores de sorptividad fueron muy elevados. No obstante la aplicación posterior del método de ensayo de la ASTM C1585 que utiliza probetas de mayor espesor y diferente tratamiento, permitió obtener los valores indicados de sorptividad para relaciones agua/cemento de 0,4;0,45 siempre que se cumplan las Buenas Prácticas constructivas.

Palabras-clave: hormigón; árido calizo; propiedades de transporte; permeabilidad; durabilidad.

\begin{abstract}
The objective of this study was to demonstrate the possibility to obtain concretes in Cuba with values of effective porosity below of $10 \%$, using limestone aggregates with high levels of absorption (higher than $1 \%$ in many cases), and values of Sorptivity below of $5 \times 10-5 \mathrm{~m} / \mathrm{s}^{1 / 2}$ as is established in the document prepared by the DURAR Latin Working Group, for structures exposed to very aggressive environments. The experimental results showed that the use of the trial method of capillary absorption of Göran Fagerlund, were obtained concretes with effective porosity below of the $10 \%$, for water/cement ratios of 0.4 and 0.45 , but the values of sorptivities were very high. Nevertheless the subsequent use of the trial method of the ASTM C1585, that use cylinders probes with bigger depth and different processing, permits to obtain the desired sorptivity values for water/cement ratios of 0.4 and 0.45 whenever would be fulfilled the Good Practices of the Construction.
\end{abstract}

Keywords: concrete; limestone aggregate; transport properties; permeability; durability.

\footnotetext{
(*) Instituto Superior Politécnico "José Antonio Echeverría" (ISPJAE) (La Habana, Cuba).

(**) Centro Técnico para el Desarrollo de los Materiales de Construcción (CTDMC) (La Habana, Cuba).
} 


\section{INTRODUCCIÓN}

La porosidad está reconocida en todo el mundo como uno de los parámetros en el hormigón endurecido de mayor influencia en los mecanismos de transporte de los agentes agresivos hacia el interior de su estructura. Más específicamente dentro del estado poroso-capilar del hormigón es la porosidad efectiva, o sea la porosidad interconectada y conectada a su vez con el exterior, la que tiene una influencia decisiva en el intercambio de humedad con el entorno y por lo tanto en la materialización de dichos mecanismos de transporte. El porcentaje de porosidad efectiva de los hormigones está considerado una medida del grado de durabilidad de las estructuras frente a los agentes agresivos. Además se ha comprobado que cuando el árido utilizado es poroso (lo que se caracteriza por su elevada absorción de agua), se incrementará con ello la porosidad y permeabilidad del hormigón (1).

Cuba es una isla larga y estrecha ubicada en el Mar Caribe, con un clima húmedo tropical y además está sometida a muy intensos niveles de agresividad, especialmente debido a los iones cloruros y sulfatos por acción del aerosol marino en su costa norte durante todo el año. Los estudios efectuados para evaluar el nivel de agresividad en el entorno marino costero donde se ubica una gran parte de las edificaciones y de toda la infraestructura constructiva del país, mostraron niveles de deposición de cloruros muy superiores a los considerados como altamente agresivos en la Norma Internacional ISO $(2,3)$. A esto se suma que más el $80 \%$ de los áridos utilizados en Cuba son calizos, triturados, con bajo contenido de finos (en especial las arenas) y que en general presentan valores de absorción elevados, que pueden llegar a ser superiores al $1 \%$ en peso.

En la normativa cubana se ha adoptado como método de referencia para evaluar la absorción capilar de los hormigones y su porosidad efectiva, el método propuesto por el investigador noruego Göran Fagerlund, que es a su vez el método recomendado en el documento elaborado por un grupo importante de investigadores de América Latina y España dentro de la comisión de la RED DURAR en el marco del CYTED (4 - 7).

Los estudios efectuados sobre testigos extraídos de estructuras de hormigón armados sometidas a ambientes altamente agresivos, como es el caso de los puentes del pedraplén que conectan a la isla grande con el Cayo Santa María, en el Norte de la provincia de Villa Clara, han mostrado valores de porosidad efectiva superiores al $10 \%$, con hormigones elaborados con relaciones Agua/Cemento de 0,4 tal como establece la Norma Cubana fundamental de especificaciones del hormigón NC 120:2007 (8) para las condiciones de exposición muy agresivas. Consecuentemente se generó la duda de que

\section{INTRODUCTION}

The porosity is well known all over the World as one of the parameters of the hardened concrete that exert a major influence in the transportation mechanisms of the aggressive agents inside the concrete structure. More specifically inside the concrete capillary porosity is the effective porosity, that is to say the porosity interconnected and connected with outside, that have a decisive influence in the humidity interchange with the environment. The percentage of the effective porosity of the concretes is considered a measure of the durability stage of the structures in front of the aggressive agents. Moreover has been proved that the use of porous aggregates in the concrete (with a high water absorption), the concrete porosity and permeability will be increased (1).

Cuba is a large and narrow Island in the Caribbean Sea, with a tropical humid climate and is submitted to strong levels of aggressive environment, especially because of chlorides and sulphides in the marine spray actions in the northern coast all the year. The studies realized to evaluate the aggressive levels in the marine coastal environment (where there is an important part of the buildings and infrastructure construction of the Country) show higher levels of chloride deposition that the considered in the International Standard ISO $(2,3)$. In addition to this more that the $80 \%$ of the aggregates used in Cuba are limestone grinded aggregates, with a low content of fines (in special the sands) and with absorption values that could be higher than $1 \%$ of the aggregate weight.

In Cuba was adopted as Standard the method proposed by the Norwegian Researcher Göran Fagerlund to evaluate the capillary absorption and the effective porosity of the concretes. This method was recommended by the document prepared by an important group of researchers of Latin America and Spain in the Commission of the DURAR net inside the framework of CYTED (4 - 7).

The studies realized over drilled cores from concrete structures submitted to very high aggressive environments, as is the case of the concrete bridges in the rocky road that connect the Island with the Santa Maria Key, in the North of Villa Clara Province, have shown values of effective porosity higher than 10\%, in concretes with Water/Cement ratios of 0.4 as is established in the Cuban Standard NC 120:2007 (8) for this type of expositions. In consequence a doubt was generated about the use of the available aggregates in the country to obtain the required values of the 
con los materiales disponibles en el país, especialmente los áridos, que constituyen entre el 75 y el $80 \%$ de la masa de los hormigones convencionales, se pudieran o no obtener dichos valores de porosidad efectiva (hasta un $10 \%$ ) y de velocidad de absorción capilar (sorptividad) no mayor a $5 \times 10^{-5} \mathrm{~m} / \mathrm{s}^{1 / 2}$.

Es importante indicar que estos parámetros establecidos de porcentaje de porosidad y de velocidad de absorción capilar en el documento de la RED DURAR para condiciones de alta agresividad ambiental, no dejan suficientemente claro si se trata de la "porosidad efectiva", o de la "porosidad total", pues en este documento aparece también como método de ensayo posible el establecido en la Norma Norteamericana ASTM C 642-06 (9) (probeta de ensayo sumergida en agua a $100{ }^{\circ} \mathrm{C}$ ). Lo cierto es que la experiencia de la realización de muchos ensayos en Cuba por ese último método y cuyos resultados se identifican en el documento de la RED DURAR como: "porosidad total", mostraron siempre valores no solo muy elevados, sino también extremadamente dispersos y en muchos casos incoherentes con la calidad mostrada en los hormigones, por lo que al parecer la elevación de la temperatura al orden de los $100{ }^{\circ} \mathrm{C}$ al nivel medio del mar, puede ejercer influencia en la deformación del diámetro de los pequeños poros capilares y falsear los valores obtenidos. Este efecto puede observarse también en los resultados de otras investigaciones recientemente publicadas, como sucede por ejemplo en la Tabla 3 del artículo sobre el desempeño de hormigones de escorias activadas con álcalis (10).

Una alternativa más interesante (reconocida también en la Norma ASTM C 642-06) es el ensayo de sometimiento de las probetas de hormigón sumergidas en agua dentro de una cámara de vacío, que aunque igualmente forzado, al menos no parece interferir de forma directa en la modificación del diámetro de los microscópicos poros capilares por incremento de la temperatura.

El parámetro S (denominado "Sorción" en el documento de la RED DURAR del CYTED) y que se interpreta como el ritmo ó velocidad de la absorción capilar, se obtiene (en este caso) utilizando uno de los parámetros establecidos por el mismo método de ensayo de Göran Fagerlund, sin embargo hay que aclarar que este parámetro nunca fue indicado por el autor del método.

El parámetro S (conceptualmente), es el establecido en el método de ensayo de la Norma Norteamericana ASTM C1585-04 (11) donde se conoce como "Sorptivity" (que traducimos libremente al español por "Sorptividad") y es la velocidad de absorción de la probeta, que está vinculada específicamente a los parámetros de "diámetro", de "forma", de "tortuosidad" o de "comunicabilidad" de los poros capilares con acceso al exterior, o sea con la effective porosity (up to 10\%) and Sorptivity (up to $5 \times 10^{-5} \mathrm{~m} / \mathrm{s}^{1 / 2}$ ) in the concretes.

Is so important to say that this parameters established in the document of the DURAR net for structures submitted under highly aggressive environments, are not clear enough if the value referred is really the "effective porosity" or the "total porosity", because is used to possible method, the test describe in the ASTM C 642-06 (9), that use the concrete sample immerse in water at $100{ }^{\circ} \mathrm{C}$. The experience of the use of this trial method many times in Cuba had shown values not only very high but extremely scattered and incoherent too with the quality found in the concretes. Seems to be that a temperature in order of the $100^{\circ} \mathrm{C}$ at the sea level, may exert some influence in the deformation of the microscopic diameters of capillary porous and the values obtained may be faulty. This effect is observed too in others researches recently published, as can be observed for example in the Table 3 from the article about the performance of concretes of activated slags with alcalis (10)

An interesting alternative (recognized too in the ASTM Standard C-642-06) is to submit the concrete cores or probes immersed in water to a vacuum camera. Though this is a forced method too, seems not to interfere at least in direct form in the modification of the diameters of the microscopic capillary porous.

The parameter S (named "Sorption" in the document of the net DURAR of CYTED) and interpreted as the rate or velocity of the capillary absorption, is obtained (in this case) using one of the parameters established by the trial method of Fagerlund, but it is necessary to clarify that this parameter never was used and mentioned by Fagerlund.

This parameter $S$ is however established in the trial method of the ASTM Standard C1585-04 (11), and is known as "Sorptivity" is the rate of capillary absorption of the probe, that depends of the diameter, form, winding and communicability of the capillary pores with access to outside, that is to say the effective porosity too. This trial method have a group of different specifications to the method of Fagerlund, for example a bigger thickness of 
anteriormente indicada porosidad efectiva. El método de ensayo establecido por la norma norteamericana para determinar la sorptividad o velocidad de absorción capilar, posee un grupo de especificaciones diferentes al método de Göran Fagerlund, por ejemplo un mayor espesor de la probeta de ensayo y un tratamiento previo diferente, por lo que por lo general durante el ensayo no se alcanza al estado de saturación y además la probeta se mantiene en un recipiente herméticamente cerrado con la parte superior sellada con una bolsa plástica, lo que crea cierta presión de vapor ambiental. Estas especificaciones sin dudas influyen muy particularmente en los resultados de los ensayos.

El objetivo del estudio es determinar si los hormigones elaborados con los áridos calizos cubanos podían o no cumplir con los dos parámetros establecidos en el documento de la RED DURAR del CYTED para las estructuras expuestas a ambientes de alta agresividad: La porosidad efectiva y la sorptividad, de manera de poder utilizar los mismos como medida del desempeño por durabilidad, no solo para proceso del diseño de las mezclas de hormigón, sino también para los hormigones en las estructuras.

\section{MATERIALES Y MÉTODOS}

La parte experimental de este estudio se presenta en dos fases que fueron el resultado del proceso sucesivo del conocimiento sobre la problemática a través de los resultados obtenidos.

En la primera fase o sea el diseño inicial del estudio se planteó la hipótesis de que era posible obtener en hormigones elaborados con áridos calizos cubanos para valores de relación agua/cemento de 0,4 (establecidas en la Norma Cubana NC 120:2007 para condiciones ambientales muy agresivas) los valores de porosidad efectiva y de sorptividad establecidos en el documento de la RED DURAR del CYTED.

La estrategia inicial fue por lo tanto demostrar la posibilidad de obtener los valores indicados en el documento de la RED DURAR del CYTED de porosidad efectiva y sorptividad en los hormigones.

El cemento utilizado fue un Cemento Pórtland Ordinario (CPO) de calidad P-35 de la fábrica "René Arcay" del Mariel en la Provincia de Artemisa, con hasta un 5\% de adición activa, tal como establece la Norma Cubana vigente (12). Este cemento es el más utilizado en toda la región occidental del país, con una composición promedio del clínquer de un $55,88 \%$ de $C_{3} S$; un $16,14 \%$ de $\mathrm{C}_{2} \mathrm{~S}$; un $10,0 \%$ de $\mathrm{C}_{3} \mathrm{~A}$ y un $7,99 \%$ de $\mathrm{C}_{4} \mathrm{AF}$.

El árido grueso utilizado procedió de la cantera "Alacranes" en la Provincia de Matanzas. Es una gravilla con the used probe, and a different treatment of the probe too. In this trial the probe does not obtain the saturation stage and the probe receive a different previous treatment. This different specifications influence particularly in the results of this trial.

The objective of this study is to determine if the concrete prepared with the Cuban limestone aggregates could obtained or not with the values of Effective porosity and Sorptivity established in the document of the net DURAR of CYTED for the concrete structures submitted to highly aggressive environments, with the objective to use these parameters to assess the durability performance, not only for the mix concrete design, but to assess the durability performance of the concretes in the structures too.

\section{MATERIALS AND METHODS}

The experimental process of the study is presented in two phases that were the result of the consecutive knowledge process about the problematic throughout the obtained results.

In the first phase (the initial design of the study) was enunciate the hypothesis that will be possible to obtain concretes with the values of Effective Porosity and Sorptivity established in the document of the net DURAR of CYTED with Cuban limestone aggregates, with water/ cement ratios of 0.4 (according with the Cuban Standard NC 120:2007 for very aggressive environmental conditions).

The initial strategy was therefore to demonstrate the possibility to obtain in the concretes the values proposed for theses parameters.

The cement used was a OPC type P-35 from the "Rene Arcay" fabric of Mariel in the Province of Artemisa, with up to $5 \%$ of active addition, as establish the Cuban Standard (12). This cement is the most used in the occidental region of the country, with an average clinker composition of $55.88 \%$ of $C_{3} S ; 16.14 \%$ of $C_{2} S ; 10.0 \%$ of $C_{3} A$ and $7.99 \%$ of $C_{4} A F$.

The gravel was from the quarry "Alacranes" in the Province of Matanzas. Is a gravel with nominal fraction of 
fracción nominal de 19,1 mm, procedente de roca caliza dura, con un valor de absorción de 0,93\%, de acuerdo con la Norma Cubana vigente (13)

Como arena se previó en esta primera etapa estudiar dos alternativas: 1) Emplear una arena de trituración de roca caliza dura, proveniente de la cantera "Dragón Camoa" y 2) Emplear una combinación de arena de roca caliza dura de la cantera "Dragón Camoa" con una arena calcárea blanda, procedente de la cantera "La Victoria II". Ambas arenas regidas por la Norma Cubana vigente (13). La arena de la cantera "Dragón Camoa", con un valor de absorción de 0,21\% y la arena de la cantera "La Victoria II", con un valor de absorción de 1,81\%.

El aditivo químico utilizado fue un superplastificanteretardador (Tipo G según la Clasificación ASTM) de segunda generación a base de Naftalen Formaldehído Sulfonato (NFS). Que cumple con los requerimientos de la Norma Cubana vigente (14).

Este estudio incluyó la aplicación del método de ensayo de absorción capilar desarrollado por Göran Fagerlund y recogido en la Norma Cubana NC 345:2011. Se elaboraron los hormigones con los diseños indicados en la Tabla 1 empleando el método de diseño de la ASTM C211.1 (15) y la combinación de los áridos recomendada en el método del Dr. O'Reilly (16). Se muestran también los resultados promedios de asentamiento por el cono de Abrams y de resistencia a compresión a 28 días obtenidos en las tres repeticiones efectuadas.

Las probetas para el ensayo de absorción capilar se extrajeron por corte de sierra a partir de las probetas normalizadas, con un espesor de $30 \mathrm{~mm}$ y del centro de las mismas se perforaron las definitivas a ensayar con una broca de $70 \mathrm{~mm}$ para que no poseyeran ninguna fisura y evitar el clásico "efecto pared" que caracteriza a los bordes de las probetas elaboradas en sus moldes. Las probetas definitivas fueron pre-acondicionadas a equilibrio de humedad con un secado a $60^{\circ} \mathrm{C}$ hasta peso constante (diferencias en peso por debajo del $0,1 \%$ ) y posterior enfriamiento en desecador. A continuación recibieron un tratamiento impermeable en las áreas laterales con parafina, se pesaron y se colocaron en sus extremos sobre cintillos de madera finos. Se garantizó una altura de agua de $5 \mathrm{~mm}$ por encima del borde inferior de las probetas y la altura constante del agua a ese nivel se mantuvo con una probeta llena de agua en posición invertida a $5 \mathrm{~mm}$ por debajo del agua en la bandeja, tal como se muestra en la Figura 1.

Todos los ensayos se realizaron con una temperatura ambiente promedio de $25^{\circ} \mathrm{C}$ y una humedad relativa promedio de $86 \%$. Las probetas se pesaron antes de ser puestas en contacto con el agua y después a intervalos
$19.1 \mathrm{~mm}$, from a hard limestone rock, with an absorption value of $0.93 \%$, according with the Cuban Standard (13).

The sand used in this first phase of the study have two alternatives: 1) Using a grinded sand from a hard limestone rock from the quarry "Dragon Camoa" (with and absorption value of $0.21 \%$ ) and 2) Using a combination of grinded sand from "Dragon Camoa" and a soft grinded sand (from calcareous rock with and absorption value of $1.81 \%$ ) of the quarry "La Victoria II". These two sands are according with the Cuban Standards (13).

The admixture used was a second generation of superplastizicer-retarder (type G as ASTM classification) based in naftalen formaldehide sulfonat (NFS), according with the Cuban Standard (14).

The study included the use of the trial method developed by Göran Fagerlund adopted in the Cuban Standard NC 345:2011. In the Table 1 are shown the design of the concretes from the design method of the ASTM C211.1 (15) and the combination of coarse and fines aggregates was obtained using the method recommended by the Dr. O'Reilly (16). In this Table are shown too the average results of the settlement of the mixes by the Abrams cone and their compression strengths at 28 days.

The probes for the capillary absorption text, were extracted by sawing from standard concrete probes, with a depth of $30 \mathrm{~mm}$ and from the center of the probes were drilled (with a drill bit of $70 \mathrm{~mm}$ of diameter) the definitive trial probes, avoiding the presence of fissures and the classic "wall-effect" in the borders. The definitive probes were pre-conditioned to humidity equilibrium with a drying at $60^{\circ} \mathrm{C}$ to obtain a constant weight and cooling them later inside a desecator. Then the probes receive an impermeable treatment in the sides with liquid paraffin, and afterwards were weighed and placed over narrow wooden bands, guarantying that the level of the water was $5 \mathrm{~mm}$ over the inferior edge of the probes, using a inverted test tube filled with water, like is showed in the Figure 1.

All the tests were realized at a environment average temperature of $25{ }^{\circ} \mathrm{C}$ an relative humidity of $86 \%$. The probes for the capillary absorption test were weighed before they were in contact with the water and later in 
Tabla 1 / Table 1

Diseños de mezclas de hormigón utilizados en la primera fase del estudio y sus resultados promedios de asentamiento por el cono y resistencia a compresión a 28 días.

Designs of the concrete mixes used in the first phase of the study and its average results about the Abrams cone settlement and the compression strength at 28 days.

\begin{tabular}{|c|c|c|c|c|c|c|c|c|c|}
\hline $\begin{array}{l}\text { Código/ } \\
\text { Code }\end{array}$ & $\begin{array}{l}\mathrm{A} / \mathrm{C} / \\
W / C\end{array}$ & $\begin{array}{c}\text { Cemento } \\
\text { P-35 / } \\
\text { Cement } \\
\left(\mathrm{kg} / \mathrm{m}^{3}\right)\end{array}$ & $\begin{array}{c}\text { Arena } \\
\text { Dragón } \\
\text { Camoa / } \\
\text { Sand }\left(\mathrm{kg} / \mathrm{m}^{3}\right)\end{array}$ & $\begin{array}{c}\text { Arena } \\
\text { Victoria / } \\
\text { Sand }(k g / \\
\left.m^{3}\right)\end{array}$ & $\begin{array}{c}\text { Gravilla } \\
\text { Alacranes } \\
\text { /Gravel } \\
\left(\mathbf{k g} / \mathbf{m}^{3}\right)\end{array}$ & $\begin{array}{c}\text { Agua / } \\
\text { Water } \\
\left(\mathbf{k g} / \mathbf{m}^{3}\right)\end{array}$ & $\begin{array}{c}\text { Aditivo / } \\
\text { Admix-ture } \\
\text { NFS } \\
\left(\mathrm{L} / m^{3}\right)\end{array}$ & $\begin{array}{c}\text { Asent. Por el } \\
\text { cono / Conus } \\
\text { Settle-ment } \\
15 \pm 2 \mathrm{~cm}\end{array}$ & $\begin{array}{l}\text { Resistencia } \\
\text { Compresión } \\
\text { a } 28 \text { días / } \\
\text { Compresion } \\
\text { strength (MPa) }\end{array}$ \\
\hline D-0.4 & 0.4 & 450 & 581 & - & 1119 & 180 & 6.432 & 17.5 & 30.5 \\
\hline D-0.45 & 0.45 & 400 & 595 & - & 1155 & 180 & 5.564 & 16.5 & 27.1 \\
\hline D-0.5 & 0.5 & 360 & 612 & - & 1188 & 180 & 3.709 & 17 & 24.4 \\
\hline D-0.6 & 0.6 & 300 & 630 & - & 1270 & 180 & 1.376 & 15 & 22.0 \\
\hline DV-0.4 & 0.4 & 450 & 421 & 180 & 1119 & 180 & 6.073 & 17 & 35.5 \\
\hline DV-0.45 & 0.45 & 400 & 433 & 187 & 1150 & 180 & 4.966 & 17 & 31.4 \\
\hline DV-0.5 & 0.5 & 360 & 448 & 192 & 1170 & 180 & 3.590 & 17 & 27.7 \\
\hline DV-0.6 & 0.6 & 300 & 458 & 196 & 1215 & 180 & 0.987 & 16 & 25.5 \\
\hline
\end{tabular}
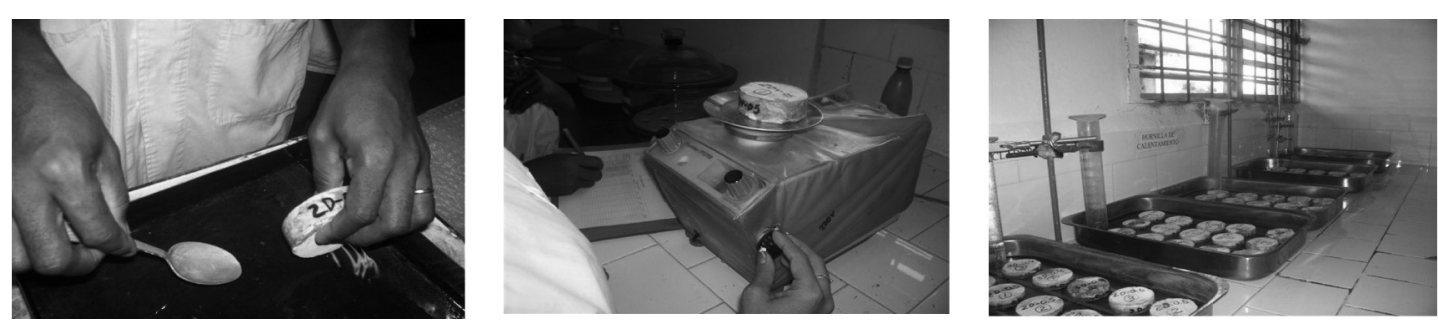

Figura 1. Tratamiento impermeable de los bordes de las probetas de ensayo con parafina, su pesaje inicial y sucesivo al concluir cada intervalo de tiempo y sus condiciones de exposición en régimen de absorción (NC 345:2011).

Figure 1. Impermeable treatment of the probes edges with parafine, weighing them in each time interval and conditions of exposition to water absorption trial (NC 345:2011).

de tiempo de $1 / 12 ; 1 / 6 ; 1 / 4 ; 1 / 2 ; 1 ; 2 ; 3 ; 4 ; 6 ; 24 ; 48$; $72 ; 96$ horas, etc. Hasta que el peso de las mismas sea aproximadamente constante.

Para cada probeta ensayada se determinaron los parámetros establecidos por el método de ensayo, o sea:

- La resistencia a la penetración del agua " $m$ "

- El coeficiente de absorción capilar " $K$ "

- La porosidad efectiva " $\xi$ "

La velocidad de absorción capilar o Sorptividad, que no es un parámetro reconocido por este método de ensayo, se determinó tal como esTablece el documento de la RED DURAR del CYTED mediante la expresión [1]:

$$
S=\frac{1}{\sqrt{m}}=\frac{h}{\sqrt{t}} \quad\left(\mathrm{~m} / \mathrm{s}^{1 / 2}\right)
$$

Para la segunda fase se realizó de igual forma el diseño total de la experimentación a partir de unos áridos calizos duros diferentes (los disponibles en el mercado: time intervals of $1 / 12 ; 1 / 6 ; 1 / 4 ; 1 / 2 ; 1 ; 2 ; 3 ; 4 ; 6 ; 24$; 48; 72; 96 hours, etc., until the weigh of them will be approximately constant.

For each tested probe was calculated the established parameters by the trial method, that is to say:

- The resistance to water penetration " $m$ "

- The capillary absorption coefficient " $k$ "

- The effective porosity " $\xi$ "

The velocity of capillary absorption (Sorptivity) is not a parameter recognized by this test method, but the document of the net DURAR of CYTED established the calcuIus of this parameter as the following equation [1]:

In the second phase was realized similarly the total design of the experiment starting from the available aggregates in the market: Gravel and sand grinded from 
Gravilla y arena de la cantera de San Cristóbal, Artemisa), pero cuyos valores de peso específico, absorción y granulometría y forma resultaron muy similares a los de Dragón Camoa y Alacranes.

Se caracterizaron nuevamente las materias primas utilizadas para la producción de los hormigones y se decidió centrar la investigación en hormigones de características similares a los que en la primera etapa cumplieron los requerimientos de valores de porosidad efectiva inferior o igual al $10 \%$ con relaciones $\mathrm{A} / \mathrm{C}$ de 0,4 y 0,45 .

En la Tabla 2 se muestran los diseños de los hormigones utilizados y los valores promedios de los asentamientos obtenidos por el cono de Abrams y las resistencias a compresión a 28 días y en la Figura 2 se muestra el montaje del método de ensayos para la determinación de la velocidad de absorción o Sorptividad según los requerimientos de la Norma ASTM C 1585-04 (11).

La absorción "I" en mm, en el método de la Sorptividad se define como el cambio en la masa que manifiesta la probeta dividida entre el producto del área de la sección transversal de la probeta de ensayo y la densidad del agua. Para este ensayo la variación de la densidad del hard limestone rocks of the quarry "San Cristóbal" in the Province of Artemisa, with values of specific gravity, absorption, granular distribution and form, very similarly to the aggregates from the quarries of "Dragon Camoa" and "Alacranes".

These raw materials were again characterized to be used in the production of concretes and was decided to focus the investigation in concretes with similar characteristics to the concretes that in the first phase reached the requirements about the values of effective porosity lower or equal to $10 \%$, with water/cement ratio of 0.4 and 0.45 .

In the Table 2 are shown the design of the concretes used and the average values of the obtained settlements by the Abrams conus and the compression strength at 28 days, and in the Figure 2 is shown how was the assembly of the test methods for the determination of the absorption velocity (Sorptivity) with the requirements of the American Standard ASTM C1585-04 (11).

The absorption "I" in $\mathrm{mm}$, in the Sorptivity test method is defined as the mass change that suffer the probe divided by the product of the cross section of the probe and the water density. To this test is obviated the variation of the water density with the temperature and is

Tabla 2 / Table 2

Diseños de mezclas de hormigón en la segunda fase del estudio y sus resultados promedios de asentamiento por el cono y resistencia a compresión a 28 días.

Designs of the concrete mixes used in the second phase of the study and its average results about the Abrams cone settlement and the compression strength at 28 days.

\begin{tabular}{|c|c|c|c|c|c|c|c|c|}
\hline $\begin{array}{l}\text { Código } \\
\text { / Code }\end{array}$ & $\begin{array}{c}\mathrm{A} / \\
\mathrm{CW} / \mathrm{C}\end{array}$ & $\begin{array}{c}\text { Cemento } \\
\text { P-35 / } \\
\text { Cement } \\
\mathrm{kg} / \mathrm{m}^{3}\end{array}$ & $\begin{array}{l}\text { Arena San } \\
\text { Cristóbal / } \\
\text { Sand } \mathrm{kg} / \mathrm{m}^{3}\end{array}$ & $\begin{array}{c}\text { Gravilla San } \\
\text { Cristóbal / } \\
\text { Gravel } \mathrm{kg} / \mathrm{m}^{3}\end{array}$ & $\begin{array}{c}\text { Agua / } \\
\text { Water } \\
L / m^{3}\end{array}$ & $\begin{array}{c}\text { Aditivo / } \\
\text { Admixture NFS } \\
\left(L / m^{3}\right)\end{array}$ & $\begin{array}{c}\text { Asent. I } \\
\text { Conus } \\
\text { settlement } 18 \\
\pm 2 \mathrm{~cm}\end{array}$ & $\begin{array}{c}\text { Resistencia Comp. } \\
\text { MPa / } \\
\text { Compresion } \\
\text { strength } 28 \text { días }\end{array}$ \\
\hline $\mathrm{P}-0.4$ & 0.4 & 450 & 763 & 931 & 180 & 3.79 & 19.5 & 39.8 \\
\hline P-0.45 & 0.45 & 400 & 781 & 955 & 180 & 3.39 & 18.0 & 31.2 \\
\hline
\end{tabular}
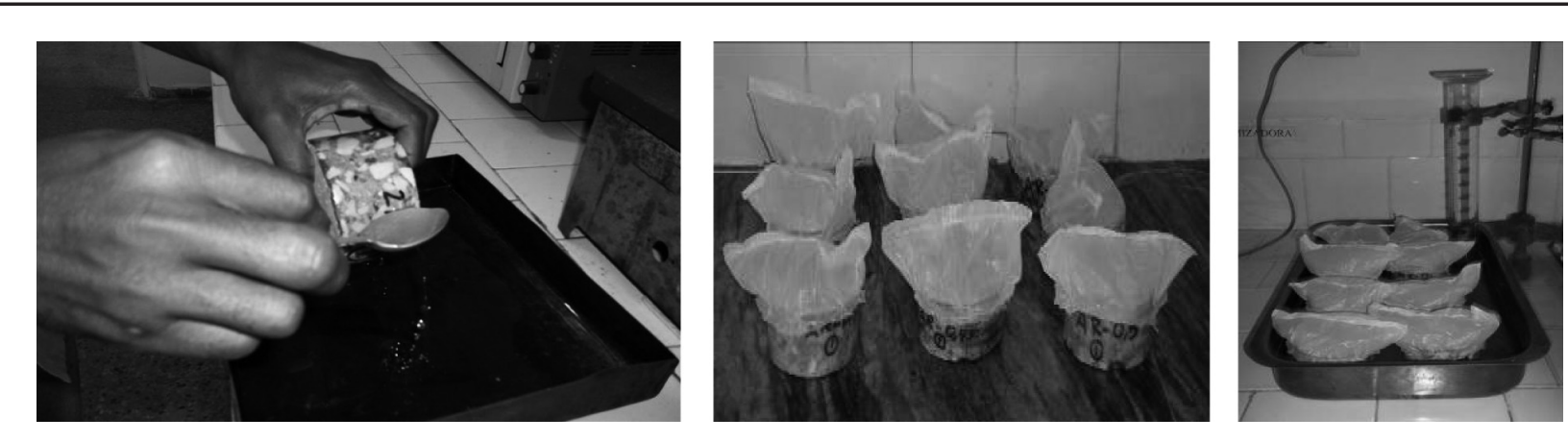

Figura 2. Tratamiento impermeable de los bordes de las probetas de ensayo, el sellaje de su parte superior y sus condiciones de exposición en régimen de absorción (ASTM C1585-04).

Figure 2. Waterproofing treatment of the borders of probes with parafine, sealing the top part of the probes and conditions of expositions to water absorption trial (ASTM C1585-04). 
agua con la temperatura es obviada y se utiliza un valor constante de $0,001 \mathrm{~g} / \mathrm{mm}^{3}$. "I" entonces se calcula por la expresión [2]: used a constant value of $0.001 \mathrm{~g} / \mathrm{mm}^{3}$. Then, "I" is calculated by the formula [2]

$$
I=\frac{m_{t}}{a \times d} \quad(\mathrm{~mm})
$$

Donde: $\mathrm{m}_{\mathrm{t}}$ : masa de la probeta de ensayo en $\mathrm{g}$.

a: Área de la sección transversal de la probeta $\left(\mathrm{mm}^{2}\right)$ $d$ : Densidad del agua $\left(0,001 \mathrm{~g} / \mathrm{mm}^{3}\right)$

Se determinaron los ajustes a una línea recta de la curva de absorción "I" en dos fases: Una inicial que va desde 1 minuto hasta las 6 primeras horas y otra secundaria que abarca desde 1 día hasta los 7 días, tal como establece la Norma:

El ritmo o velocidad inicial de absorción de agua, se define entonces como la pendiente de la línea que sea el mejor ajuste a "I" representado frente a la raíz cuadrada del tiempo. La pendiente se obtiene utilizando el análisis de regresión lineal por los mínimos cuadrados de todos los puntos desde 1 min hasta 6 horas y tiene que garantizar un ajuste con un coeficiente de correlación no inferior al $98 \%$.

El ritmo o velocidad secundaria de absorción de agua, se define como la pendiente de la línea que sea el mejor ajuste a "I" representado frente a la raíz cuadrada del tiempo. Utilizando el análisis de regresión lineal por los mínimos cuadrados de todos los puntos desde 1 día a 7 días y tiene que garantizar también un ajuste con un coeficiente de correlación no inferior al 98\%.

Los ritmos (o velocidades) promedios inicial y secundario de absorción de agua fueron calculados al 0,1 x 10-4 $\mathrm{mm} / \mathrm{s}^{1 / 2}$ más cercano, para las tres probetas ensayadas, tal como establecen los requerimientos normativos.

\section{RESULTADOS Y DISCUSIÓN}

En la Tabla 3 se indican los valores promedios obtenidos para la porosidad efectiva y la sorptividad aplicando el método de Göran Fagerlund para cada uno de los diseños de mezclas y en la Figura 3 se muestra como ejemplo las cuatro curvas obtenidas para los diseños de mezclas de hormigón del Grupo D (Relaciones agua/ cemento 0,$4 ; 0,45 ; 0,5$ y 0,6$)$ sobre la absorción capilar de los hormigones con relación a la raíz cuadrada del tiempo, donde puede apreciarse claramente el fenómeno de saturación de la probeta que caracteriza este ensayo. Hay que indicar que todas las curvas para los hormigones del Grupo DV presentaron los mismos comportamientos.
Where: $m_{t}$ : mass of the test probe in $g$.

a: Area of the cross section of the probe $\left(\mathrm{mm}^{2}\right)$ d: Water density $\left(0.001 \mathrm{~g} / \mathrm{mm}^{3}\right)$

Were realized the adjusts to the straight line of the absorption function " $\boldsymbol{I}$ " in two phases: Initial from 1 min to the first 6 hours and the secondary from 1 day to 7 days, as is established in the Standard:

The rate or initial velocity of water absorption is defined as the slope of the line that offer the best adjust to "I" versus the square root of the time. The slope is obtained through a lineal regression analyze by the minimum square of all the points from 1 min to 6 hours. It's necessary to obtain adjust with a correlation coefficient of $98 \%$ at least.

The rate o secondary velocity of water absorption is defined as the slope of the line that offer the best adjust to "I" versus the square root of the time, using a lineal regression analyze by the minimum square of all the points from 1 day to 7 days. It's necessary to obtain adjust with a correlation coefficient of $98 \%$ at least.

The average rates (or velocities) initial and secondary of water absorption were calculated at the next value of $0.1 \times 10^{-4} \mathrm{~mm} / \mathrm{s}^{1 / 2}$ for the three probes tested, as is established in the standard requirements.

\section{RESULTS AND DISCUSSION}

In the Table 3 are indicated the average values obtained for the Effective Porosity and the Sorptivity, applying the test method of Göran Fagerlund for each concrete mix design and in the Figure 3 is shown as an example, the four curves of capillary absorption obtained for the concrete mixes designs of the Group $D$ (Water/cement ratios of $0.4 ; 0.45 ; 0.5$ and 0.6 ) respect to the square root of the time, where it can appreciate clearly the phenomena of saturation of the probe, that is an special characteristic of this test. It is necessary to say that all the curves for the concretes of the Group DV had the same performances. 
Tabla 3 / Table 3

Valores promedios obtenidos de coeficiente de absorción $(k)$, resistencia a la penetración del agua (m), porosidad efectiva $(\xi)$ y Sorptividad (S) a partir del ensayo de absorción capilar de agua.

Average values obtained about the absorption Coefficient $(k)$, the resistance to water penetration $(m)$, the effective porosity $(\xi)$ and the Sorptivity $(S)$ starting from the water absorption trial.

\begin{tabular}{|c|c|c|c|c|c|}
\hline \multirow{2}{*}{$\begin{array}{l}\text { Códigol } \\
\text { Code }\end{array}$} & \multirow[b]{2}{*}{$\mathrm{K}\left(\mathrm{kg} / \mathrm{m}^{2} . \mathrm{s} 1 / 2\right)$} & \multirow[b]{2}{*}{$m\left(s / m^{2}\right)$} & \multicolumn{2}{|c|}{ Porosidad Efectiva / Effective Porosity } & \multirow{2}{*}{$\begin{array}{c}\text { Sorptividad / } \\
\text { Sorptivity } \\
(\mathrm{m} / \mathrm{s} 1 / 2)\end{array}$} \\
\hline & & & $\xi(\%)$ & $\begin{array}{l}\text { Desviación Típica / } \\
\text { Standard Deviation (\%) }\end{array}$ & \\
\hline D-0.4 & $6.56 \times 10-3$ & $1.08 \times 108$ & 6.96 & 0.13 & $9.73 \times 10-5$ \\
\hline $\mathrm{D}-0.45$ & $9.42 \times 10-3$ & $8.43 \times 107$ & 8.57 & 0.138 & $1.10 \times 10-4$ \\
\hline D-0.5 & $1.34 \times 10-2$ & $6.14 \times 107$ & 10.30 & 0.167 & $1.29 \times 10-4$ \\
\hline D-0.6 & $1.90 \times 10-2$ & $5.53 \times 107$ & 14.00 & 0.26 & $1.36 \times 10-4$ \\
\hline DV-0.4 & $5.03 \times 10-3$ & $1.33 \times 108$ & 5.60 & 0.11 & $8.69 \times 10-5$ \\
\hline DV-0.45 & $7.32 \times 10-3$ & $9.36 \times 107$ & 6.99 & 0.13 & $1.04 \times 10-4$ \\
\hline DV-0.5 & $1.02 \times 10-2$ & $7.09 \times 107$ & 8.57 & 0.171 & $1.19 \times 10-4$ \\
\hline DV-0.6 & $1.79 \times 10-2$ & $4.61 \times 107$ & 12.02 & 0.38 & $1.47 \times 10-4$ \\
\hline
\end{tabular}

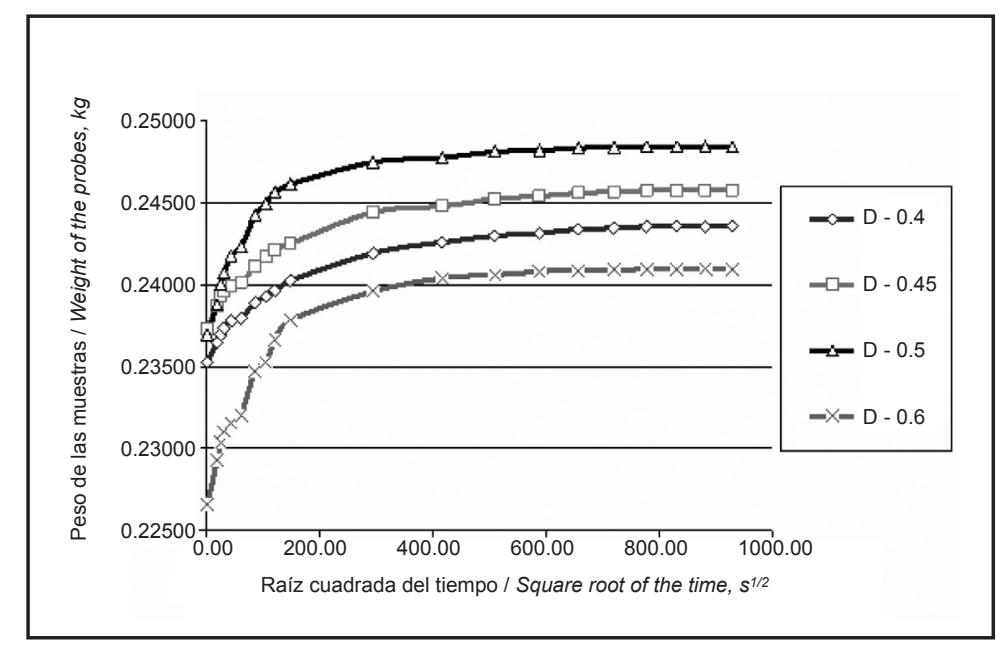

Figura 3. Curvas de absorción capilar de agua obtenidas para los diseños de mezcla del grupo "D" a través del cambio del peso de las probetas con el tiempo.

Figure 3. Water capillary absorption curves obtained for the mix designs of group " $D$ " through the weight changes of the probes with the time.

Los resultados de esta primera fase del estudio resultaron muy interesantes y solo se pudo cumplir la primera parte de la hipótesis planteada, en lo relativo a los valores de la porosidad efectiva " $\xi$ ", pues se comprobó que para hormigones con relaciones agua/cemento $0,4 \mathrm{y}$ 0,45 , con áridos calizos triturados y manteniendo la adecuada disciplina tecnológica en cuanto a garantizar una compactación completa del hormigón y un cuidadoso curado, se obtuvo una porosidad efectiva inferior al $10 \%$ que caracteriza (según el documento de la Red Durar) a los hormigones que pueden desempeñarse con una adecuada durabilidad en un ambiente agresivo. En tanto que los hormigones con relaciones agua/cemento de 0,5 y 0,6 clasifican en el entorno de porosidad efectiva entre 10 y $15 \%$, o sea de moderada calidad, permeables y no adecuados por su desempeño para ambientes agresivos. Se puede incluso observar que algunos de los valores
The results of this first phase of the study result were very interesting and only was proved the first part of the referred hypothesis, respect to the values of the Effective Porosity " $\xi$ " because was proved that the concretes with a water/cement ratios of 0.4 and 0.45 with limestone grinded aggregates and maintaining the suitable technological discipline to garantir a complete concrete consolidation and an appropriate concrete curing, is possible to obtain a value of the Effective Porosity lower than $10 \%$, that characterize (as said the document of the net DURAR) the concretes that will have a suitable performance in aggressive environments, while the concretes with water/cement ratios of 0.5 and 0.6 that will have a moderate quality, are permeable and not adequate for aggressive environments. It is possible even to see that some of the values obtained for the water/cement ratios of 0.45 in the case of concretes which don't have 
obtenidos para la relación agua/cemento de 0,45, especialmente para los hormigones donde no se combinan las dos arenas están muy cercanos al $10 \%$.

Sin embargo la hipótesis no se cumple para los valores obtenidos de Sorptividad a través del ensayo de Göran Fagerlund, pues estos valores están todos por encima de $8,51 \times 10^{-5} \mathrm{~m} / \mathrm{s}^{1 / 2}$, en tanto que el parámetro límite establecido por la Red DURAR del CYTED para las estructuras de hormigón con un espesor de recubrimiento del acero de $30 \mathrm{~mm}$, en ambiente muy agresivo, establece un valor máximo de $5 \times 10^{-5} \mathrm{~m} / \mathrm{s}^{1 / 2}$.

Estos resultados provocaron incertidumbre en los ejecutores sobre la eficacia de la medición de la Sorptividad a partir de un método de ensayo que no la contempla como parámetro, más aún existiendo en estos momentos una Norma Norteamericana, la ASTM C1585-04 (11) que está diseñada para medir concretamente este parámetro en los hormigones en dos fases: Inicial y final. Se efectuó entonces un estudio detallado de esta norma y se materializó su montaje en el laboratorio atendiendo a las diferencias que posee este método con respecto al de absorción capilar.

En la Tabla 4 se muestran los valores promedios obtenidos de absorción con el tiempo, a partir de las tres réplicas de los ensayos para los hormigones con relaciones Agua/Cemento de 0,4. Esto se efectuó de igual forma para la relación Agua/Cemento de 0,45. a combination of the two types of sands were very close to the $10 \%$ of Effective Porosity.

However the Hypothesis is not fulfilled by the values obtained of Sorptivity in the test method of Göran Fagerlund, because all the values are higher than $8.51 \times 10^{-5} \mathrm{~m} / \mathrm{s}^{1 / 2}$, whereas the limited parameter established by the net DURAR of CYTED for concrete structures with a rebars cover of $30 \mathrm{~mm}$, submitted to very aggressive environment, established a maximum value of $5 \times 10^{-5} \mathrm{~m} / \mathrm{s}^{1 / 2}$.

These results provoke uncertainty in the executers about the effectiveness of the Sorptivity measurement, because this test method not includes it as a parameter, even more when exist a Nor American Standard: The ASTM C1585-04 (11) that is designed specifically to obtain this parameter in the concretes I two phases: Initial and Final. The executers study in detail this document and carried out the assembly of this test method in the laboratory, taking account the differences respect the method of capillary absorption.

In the Table 4 are shown the average values of absorption obtained with the time, from the three trial repetitions for concretes with water/cement of 0.4 and 0.45 .

Tabla 4 / Table 4

Valores promedios obtenidos en la masa de las probetas para los hormigones con relación $A / C$ de 0,4. Average values obtained from the probes mass for the concretes with W/C ratio of 0.4

\begin{tabular}{|c|c|c|c|c|c|}
\hline \multicolumn{6}{|c|}{ Diámetro / Diameter $(\mathrm{mm}): 98.6$ Espesor / Thicness $(\mathrm{mm}): 48.9$ Área expuesta / Exposed area: $7.631 \mathrm{~mm}^{2}$} \\
\hline \multicolumn{2}{|c|}{ Tiempo del ensayo / Time of trial } & \multirow{2}{*}{$\begin{array}{l}\text { Raiz C. tiempo /Square } \\
\text { root of Time }\left(\mathbf{s}^{1 / 2}\right)\end{array}$} & \multirow{2}{*}{$\begin{array}{c}\text { Masa / } \\
\text { Mass }(g)\end{array}$} & \multirow{2}{*}{$\begin{array}{l}\Delta \text { Masa I } \\
\text { Mass }(g)\end{array}$} & \multirow{2}{*}{$\begin{array}{c}\Delta \text { Masa/área/densidad del agua }(\mathrm{mm}) / \\
\text { Mass/area/water density }\end{array}$} \\
\hline Días / Days & $\mathbf{s}$ & & & & \\
\hline & 0 & 0 & 910.8 & 0.00 & 0.0000 \\
\hline & 60 & 8 & 911.5 & 0.71 & 0.0925 \\
\hline & 300 & 17 & 912.1 & 1.27 & 0.1663 \\
\hline & 600 & 24 & 912.5 & 1.66 & 0.2175 \\
\hline & 1200 & 35 & 912.9 & 2.11 & 0.2765 \\
\hline & 1800 & 42 & 913.2 & 2.35 & 0.3078 \\
\hline & 3600 & 60 & 913.7 & 2.88 & 0.3771 \\
\hline & 7200 & 85 & $\begin{array}{l}914.3 \\
\end{array}$ & 3.49 & 0.4570 \\
\hline & 10800 & 104 & 914.7 & 3.87 & 0.5070 \\
\hline & 14400 & 120 & 915.0 & 4.14 & 0.5426 \\
\hline & 18000 & 134 & 915.2 & 4.40 & 0.5764 \\
\hline & 21600 & 147 & 915.4 & 4.59 & 0.6009 \\
\hline 1 & 92220 & 304 & 917.5 & 6.62 & 0.8681 \\
\hline 2 & 193200 & 440 & 918.8 & 7.99 & 1.0476 \\
\hline 3 & 268500 & 518 & 919.8 & 8.94 & 1.1715 \\
\hline 5 & 432000 & 657 & 921.1 & 10.30 & 1.3498 \\
\hline 6 & 527580 & 726 & 921.6 & 10.77 & 1.4116 \\
\hline 7 & 622200 & 789 & 922.1 & 11.25 & 1.4736 \\
\hline 8 & 691200 & 831 & 922.4 & 11.61 & 1.5209 \\
\hline
\end{tabular}




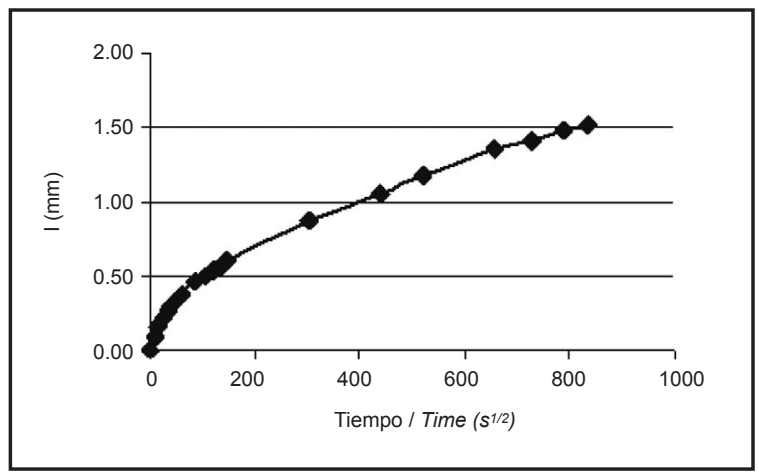

Figura 4. Gráfico promedio de la Sorptividad (Velocidad de absorción) para los hormigones con relación A/C de 0.4. Figure 4. Average values Graph of Sorptivity (absorption rate) for concretes with A/C ratio of 0.4.

Tabla 5 / Table 5

Valores promedios de las velocidades de absorción en los hormigones. Average values of the absorption velocities in the concretes.

\begin{tabular}{|c|c|c|c|c|}
\hline $\begin{array}{c}\text { Serie Identificación / } \\
\text { Serie Identification }\end{array}$ & $\begin{array}{c}\text { Velocidad Inicial } \\
\text { de Absorción / Velocity of } \\
\text { the Initial Absorption } \mathbf{( m m /} \\
\left.\mathbf{s}^{1 / 2}\right)\end{array}$ & $\begin{array}{c}\text { Coeficiente } \\
\text { de Correlación / } \\
\text { Correlation Coefficient } \\
(\boldsymbol{r})\end{array}$ & $\begin{array}{c}\text { Velocidad Secundaria de } \\
\text { absorción / Velocity of } \\
\text { the Secondary Absorption } \\
(\mathbf{m m} / \mathbf{s} / \mathbf{2})\end{array}$ & $\begin{array}{c}\text { Coeficiente de } \\
\text { Correlación / } \\
\text { Correlation Coefficient }(\boldsymbol{r})\end{array}$ \\
\hline P- 0.4 & $3.5 \times 10-3$ & 0.98 & $1.3 \times 10-3$ & 1.00 \\
\hline P- 0.45 & $5.4 \times 10-3$ & 0.99 & $2.2 \times 10-3$ & 1.00 \\
\hline
\end{tabular}

En la Figura 4 se muestra como ejemplo el gráfico promedio correspondiente de la Absorción "I" en mm, en función de la raíz cuadrada del tiempo para la relación Agua/Cemento de 0,4.

Finalmente en la Tabla 5 se muestran los valores promedios obtenidos de las Velocidades de Absorción Inicial y Secundaria $\left(\mathrm{mm} / \mathrm{s}^{1 / 2}\right)$ para las dos relaciones Agua/Cemento. Puede observarse que todos los valores promedios e individuales de las velocidades de absorción (Sorptividad) tanto iniciales como secundarios son inferiores a lo establecido por el documento de la RED DURAR del CYTED, o sea a $5 \times 10^{-2} \mathrm{~mm} / \mathrm{s}^{1 / 2}$.

Los valores obtenidos para la Sorptividad tienen un comportamiento similar a otras experiencias anteriores en los Estados Unidos con la utilización de esta Norma de ensayos, como es el caso del estudio efectuado como parte de la iniciativa P2P (Prescription to Performance) en los laboratorios de la Asociación Nacional del Hormigón Premezclado (NRMCA) $(17,18)$.

Los hormigones elaborados con áridos calizos cubanos de elevada absorción y con relaciones Agua/Cemento de 0,4 y 0,45 pueden cumplir con los requerimientos de hasta un $10 \%$ de porosidad efectiva y con valores de Sorptividad inferiores a $5 \times 10^{-5} \mathrm{~m} / \mathrm{s}^{1 / 2}\left(5 \times 10^{-2} \mathrm{~mm} / \mathrm{s}^{1 / 2}\right)$ siempre y cuando se garantice el cumplimiento estricto de las "buenas prácticas" durante el hormigonado de las estructuras, o sea un vertido continuo y uniforme (sin
An example of an average graphic about the Absorption value " $\mathrm{I}$ " in $\mathrm{mm}$, in relation with the square root of the time for a water/cement ratio of 0.4 , is shown in the Figure 4

Finally in the Table 5 can be seen the average values of the Initial and Secondary Absorption Velocity (Sorptivity) in $\mathrm{mm} / \mathrm{s}^{1 / 2}$ for the two water/cement ratios. It is possible to observe that all the averages and individual values of the Absorption Velocity (Sorptivity), initials and secondaries are lowers to the values established in the net DURAR of CYTED, that is to say $5 \times 10^{-2} \mathrm{~mm} / \mathrm{s}^{1 / 2}$.

The values obtained for the Sorptivity have a similar performance that other preceding experiences in the United States with the use of this Test. That is the case of the study realized as part of the P2P Initiative (Prescription to Performance) in the laboratories of the National Ready-Mixed Concrete Association (NRMCA) (17, 18).

The concretes prepared with Cuban limestone aggregates with a high absorption and water/cement ratios of 0.4 and 0.45 may satisfy the requirements established with up to $10 \%$ of Affective Porosity and Sorptivity values up to $5 \times 10^{-5} \mathrm{~m} / \mathrm{s}^{1 / 2}\left(5 \times 10^{-2} \mathrm{~mm} / \mathrm{s}^{1 / 2}\right)$, whenever will be absolutely guarantee the strict fulfillment of "Good Practices" during the concreting of the structures, that is to say a continuous and uniform concrete pouring 
juntas), una buena compactación y un curado continuo y uniforme en los tiempos mínimos establecidos en las Normas Cubanas en dependencia del tipo de cemento utilizado.

La Sorptividad, o ritmo de absorción de agua de los hormigones debe determinarse a través del método de ensayo establecido en la Norma Norteamericana ASTM C1585-04 y no aplicar una extrapolación a partir del parámetro " $m$ " (resistencia a la penetración del agua) del método de ensayo de Göran Fagerlund, tal como se propone en el documento de la RED DURAR del CYTED. Este método de ensayo fue finalmente adoptado a propuesta de los autores de este artículo, como Norma Cubana por el Comité Técnico de Normalización CTN 37 "Hormigón reforzado y Morteros".

Los valores de porosidad efectiva " $\xi$ " y de Sorptividad " $S$ " de los hormigones, son particularmente valiosos y pueden emplearse como parámetros para medir el desempeño por durabilidad de los hormigones, tanto a escala del diseño de las mezclas de hormigón en los laboratorios, como en los hormigones ya colocados en las estructuras. De esta forma ambos parámetros pueden considerarse especificaciones por desempeño para las estructuras de hormigón armado expuestas a ambientes muy agresivos.

Las especificaciones de carácter prescriptivo, que están establecidas en una buena parte de la Normativa Internacional (un valor límite de relación Agua/Cemento, un consumo mínimo de cemento en la mezcla y un valor mínimo de la resistencia característica a la compresión del hormigón) han demostrado ser insuficientes, pues a través de ellas no es posible valorar la aplicación o no, de las buenas prácticas constructivas en el proceso de ejecución de las estructuras y cuya importancia es decisiva para su durabilidad.

\section{CONCLUSIONES}

- La investigación efectuada demostró la factibilidad de producir en Cuba hormigones con relaciones Agua/ Cemento de 0,4 y 0,45 y la utilización de áridos calizos cubanos, que cumplan con los valores de porosidad efectiva y de velocidad de absorción capilar (Sorptividad) establecidos para estos parámetros por la RED DURAR del CYTED.

- Se hace indispensable el estricto cumplimiento de las buenas prácticas constructivas (en especial un hormigonado continuo y uniforme sin la formación de juntas frías, oquedades ni fisuras, con una buena compactación de la mezcla y un curado continuo (sin dejar secar la superficie) en los tiempos establecidos por las Normas. (without cold joints), a complete consolidation and a continuous curing of the concrete in the minimum times established in the Cuban Standards, in depend on the type of cement used.

The Sorptivity, or concrete absorption rate have to be calculated throughout the test method established in the Nor American Standard ASTM C1585-04 and not to apply an extrapolation from the parameter " $m$ " (resistance to water penetration) of the test method of Göran Fagerlund, as is proposed by the document of the net DURAR from CYTED. This test method (ASTM C1585-04) was finally adopted too in Cuba by a proposed of the authors of this article, as a Cuban Standard, by the Normalization Committee CTN 37 "Reinforced concrete and Mortars".

The values of the concrete Effective Porosity " $\xi$ " and Sorptivity "S", are particularly valuables, and can be used as parameters to measure the durability performance of the concretes, whether to a laboratory scale during the design of the mix concretes in the laboratories or whether in the concretes poured in the structures. So that these two parameters can be considered as Performance Specifications for the reinforced concrete structures exposed to very aggressive environments.

The prescriptive specifications, that are normally established in a great part of the International Standards (with a limited value of water/cement ratio; a minimum value of cement content in the mix; a minimum characteristic compression strength, etc.) have shown to be insufficient, because through them is not possible to evaluate the use or not of the Good Construction Practices in the execution process of the structures that have a decisive importance in the structures durability.

\section{CONCLUSIONS}

- The research carried out have demonstrate the feasibility to produce in Cuba concretes with water/cement ratios of 0.4 and 0.45 and using Cuban limestone aggregates, that satisfy the values of Effective Porosity and Capillary Absorption Velocity (Sorptivity) established by the net DURAR of CYTED.

- It's indispensable the strict fulfillment of the Constructive Good Practices (specially a continuous and uniform concreting of the structures, without the formation of cold joints, honeycombs, fissures and cracks, with a good consolidation of the concrete and a continuous curing (without permit the drying of the surface) all the time established in the technical standards. 
- Es factible introducir en la Normativa Cubana la exigencia de los dos parámetros (Porosidad efectiva y Sorptividad) como especificaciones por desempeño, tanto para la etapa de diseño de las mezclas de hormigón, como para las estructuras ya elaboradas.

\section{AGRADECIMIENTOS}

Los autores agradecen al Ministerio de la Construcción de la República de Cuba y en especial a la Dirección de Desarrollo Tecnológico, el financiamiento logrado para la realización de esta investigación y a la Dirección de Normalización por el apoyo logrado para la adopción de una nueva Norma Cubana y la generalización de los resultados en la normativa vigente.
- Is feasible to introduce in the Cuban Standard the fulfilled requirements of the two parameters (Effective Porosity and Sorptivity) as performance specifications, whether to a laboratory scale during the design of the mix concretes in the laboratories or whether in the concretes poured in the finished structures.

\section{ACKNOWLEDGEMENTS}

The authors want to express their acknowledgments to the Ministry of Construction of Cuba and especially to the Direction of Technological Development, because of the finantial support of the investigation. To the Direction of Normalization too, because its support to materialize the results of the investigation in new national technical normatives.

\section{REFERENCIAS / REFERENCES}

(1) Neville, A.; Brooks, J., Tecnología del concreto. P. 205 D.F., Editorial Trillas, México D.F. (1992).

(2) Castañeda, A.; Corvo, F.; Howland, J.; Pérez, T. "Atmospheric Corrosion of concrete reinforced bars in tropical coastal regions". Memories of the European Congreso of Corrosión (EUROCOR 2011). Stocolm, Sweden. September 2011.

(3) International Standard ISO 9223:1992 "Corrosion of metals and alloys - Corrosivity of atmospheres. Classification".

(4) Uller, L.; Troconis de Rincón O., Alanis I.; Helene P.; Mejias de Gutierrez R.; O’Reilly V.; Andrade C.; Carpio J.J.; Díaz I.; Salta M.; Rodríguez G.; Romero de Carruyo A.; Sagues A. "Manual for inspecting, evaluating and diagnosing corrosion in reinforced concrete structures", DURAR Thematic Network XV.B. Durability of rebars, CYTED Iberoamerican Program Science and Technology for Development, Maracaibo, Venezuela (1998).

(5) Fagerlund, G. "On the Capillarity of concrete" Nordic Concrete Research. Oslo, Noruega. Vol. Diciembre (1982).

(6) Cuban Standard: NC 345:2011 "Hormigón endurecido - Determinación de la absorción de agua por capilaridad".

(7) Spanish Standard: UNE 83982 "Durabilidad del hormigón. Métodos de ensayo. Determinación de la absorción de agua por capilaridad del hormigón endurecido. Método de Fagerlund.

(8) Cuban Standard: NC 120:2007 "Hormigón hidráulico - Especificaciones".

(9) Nor American Standard ASTM C642-06 (2006) "Standard Test Method for Density, Absorption, and Voids in Hardened Concrete".

(10) Bernal, S.A. ; Mejía de Gutierrez, R.; Pedraza A. L.; Provis J.L.; Rodríguez E. D.; Delvasto S. "Effect of binder content on the performance of alkali-activated slag concretes". Cem. Concr. Res., Vol. 41 (2011) pp.1-8. http://dx.doi.org/10.1016/j.cemconres.2010.08.017

(11) Nor American Standard: ASTM C 1585-04 (2004) "Standard test method for measurement of rate of absorption of water"

(12) Cuban Standard: NC 95:2001 "Cemento Pórtland. Especificaciones".

(13) Cuban Standard: NC 251:2005 "Áridos para hormigones hidráulicos - Requisitos".

(14) Cuban Standard: NC 228-1:2005 "Aditivos para hormigones, morteros y pastas - Parte 1 Aditivos para hormigón. Requisitos.

(15) Nor American Standard: ASTM C211.1-91 (reaprobada en el 2002) "Práctica normativa para seleccionar las proporciones de un hormigón Normal, de alta densidad y masivo".

(16) O'Reilly, V. Método de dosagem de concreto de elevado desempenho PINI Ltda. Sao Paulo. Brazil (1998).

(17) Bickley, J.; Hooton R.; Hover K.; "Performance Specifications for Durable Concrete. Current Practices and Limitations". Concrete International. USA. September (2006).

(18) Obla, K.; Lobo C. "Experimental case of demostrative study about the advantages of the performance specifications". RMC Research Foundation (NRMCA Initiative P2P). Enero 2006. 